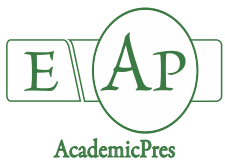

Tomic D et al. (2020)

Notulae Botanicae Horti Agrobotanici Cluj-Napoca 48(1):284-293

DOI: $10.15835 /$ nbha48111814

Research Article

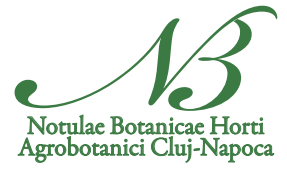

\title{
Seed testing of foliar-fertilised red clover crops after various periods of storage
}

\section{Dalibor TOMIĆ ${ }^{1 *}$, Vladeta STEVOVIĆ ${ }^{1}$, Dragan ĐUROVIĆ ${ }^{1}$, Rade STANISAVLJEVIĆ ${ }^{2}$, Milomirka MADIĆ ${ }^{1}$, Mirjana PETROVIĆ 3 , Đorđe LAZAREVIĆ ${ }^{3}$, Jasmina KNEŽEVIĆ ${ }^{4}$}

\author{
${ }^{1}$ University of Kragujevac, Faculty of Agronomy, Cara Dušana 34, 32000 Čačak, Serbia; dalibort@kg.ac.rs ('corresponding author) \\ ${ }^{2}$ Institute for Plant Protection and Environment, Teodora Drajzera 9, 11000 Belgrade, Serbia; stanisavljevicrade@gmail.com \\ ${ }^{3}$ Institute of Forage Crops, +38137251 Globoder, Kruševac, Serbia; mirjana.petrovic@ikbks.com \\ ${ }^{4}$ Univerzity of Priština, Faculty of Agriculture, Kopaonička bb, 38219, Lešak, Serbia; jasmina.kneska@gmail.com
}

\begin{abstract}
The aim of the present study was to analyse the effect of foliar fertilisation of red clover (Trifolium pratense L.) crops with cobalt, boron and phosphorus-potassium, which could significantly increased seed yield, on seed quality after different periods of storage. The experiment involving four red clover cultivars and four foliar treatments was laid out in a randomised block design with four replications and with a plot size of $5 \mathrm{~m}^{2}$. Red clover cultivars 'K-37', 'K-39', 'Una' and 'Viola' were planted at a seeding rate of $18 \mathrm{~kg} \mathrm{ha}^{-1}$. Foliar fertilisation with cobalt, boron and phosphorus-potassium was carried out during intensive growth (at $\mathrm{BBCH}$ 34-36) in the second year of cultivation. After all storage periods, red clover cultivars differed in root length, seedling mass and hard seededness under all foliar fertilisation treatments. In all storage periods, foliar treatments did not affect germination, stem length, seedling mass and percentage of hard seed in any cultivar (no significant cultivar/foliar treatment interaction). At 20 months of storage, there were no significant differences between foliar treatments and the unfertilised control in any of the studied traits. Foliar nutrients were applied prior to the emergence of generative organs; therefore, the absence of their positive effect on seed development can be associated with their overall short-term effect. The relationship between seed quality and the content of mineral nutrients in the seed after their foliar application at different stages of crop development should be a topic for future research.
\end{abstract}

Keywords: foliar fertilisation; red clover; seed quality parameters

\section{Introduction}

Important indicators of legume seed quality are germination, hard seededness and seedling growth parameters. Germination and seedling emergence are critical growth stages in plant development, which determine crop density, growth rate and final yield (Desai et al., 1997). Seedling growth parameters are important seed quality components which affect the success of crop establishment, growth and productivity of 
plants (Sawan et al., 2009). Dormancy is the inability of a viable seed to germinate immediately after harvest, even under favourable conditions (Copeland and McDonald, 1995; Aydin and Uzun, 2001). Hard seededness is a special type of dormancy found only in legumes, and in species of the genus Trifolium it is mainly the consequence of seed coat impermeability to water (Desai et al., 1997; Ates, 2011). With aging, the seed loses hard seededness (Asci et al., 2011). Depending on plant species, the release of hard seededness may take from a few days to several years (Baskin and Baskin, 2004).

Outside their optimal range, abiotic and biotic factors can have a negative effect on seed germination and seedling emergence, especially under stressful conditions e.g. acid soils, insufficiently cultivated top soil, low temperatures, excess or lack of water, pathogenic soil microorganisms, seed damage by pests and chemicals (Sawan et al., 2009). Proper mineral nutrition, in particular macro- and micronutrients necessary for the formation of generative organs, seed setting and filling, may have a positive effect on yield and seed quality. In Southeast Europe, red clover seed crops are commonly established on acid soils, where certain macro- and micronutrients are less available to plants. As determined by Tomić et al. $(2011 ; 2014 ; 2015)$, on such soils, foliar fertilisation of red clover crops with cobalt, boron, phosphorus and potassium can positively affect seed yield. Cobalt has an important role in a number of physiological processes (Mathur et al., 2006; Jayakumar et al., 2007; Jayakumar and Jallel, 2009). In addition, cobalt is the central atom in the porphyrin structure of cobalamin coenzyme and is essential for the nodulation and development of bacteroids (Collins and Kinsela, 2011). Given the low mobility of Co in the plant (Austenfeld, 1979) and its faster movement from aboveground parts to the root rather than in the opposite direction (Danilova et al., 1970; Palit et al., 1994), foliar treatment is assumed to lead to a more efficient and optimal status of cobalt in the root and in the nodules, in comparison with soil application. Boron is actively involved in cell division, flowering, fruit ripening, nitrogen and carbohydrate metabolism, plant resistance to diseases, and in many other reactions in which it acts as a catalyst (Goldbach et al., 2001; Farooq et al., 2011). Accordingly, its deficiency causes a significant decline in the seed yield of many plant species. High concentrations of aluminium ions in acidic soils limit boron uptake (Matsumoto, 2000; Yau, 2000). Boron is relatively immobile in plants, and thus its availability is essential at all stages of growth, especially during seed development (Waqar et al., 2012). The authors also emphasise that research for improving crop yields must move beyond applications of B based on general recommendations, and that deriving methods to predict site-specific deficiencies (e.g. soil or plant tests) are essential since the potential for B toxicity is large and the difference between deficiency and toxicity is very narrow.

Phosphorus and potassium are necessary for the growth of both vegetative and generative organs in leguminous plants (Hégh-Jensen et al., 2001; Abbasi et al., 2016). Phosphorous is easily fixed by clay minerals that are abundant in acidic soils, including various iron oxides and kaolinite, hence rendering it unavailable for root uptake (Zheng, 2010).

In this research, it was assumed that foliar treatments with cobalt, boron, phosphorus and potassium on an acidic soil would increase seed yield and seed quality of red clover cultivars differing in total biomass production. Their effect on seed yield was analysed in earlier studies (Tomić et al., 2011; 2014; 2015). The objective of this study was to evaluate major quality characteristics, i.e. germination, seedling growth parameters and hard seededness of the seed obtained from foliar-fertilised red clover crops, after various periods of storage.

\section{Materials and Methods}

\section{Soil properties}

A field experiment was established at a trial field of the Veterinary Extension Service in Čačak, Serbia (43 ${ }^{\circ} 4^{\prime} 39.06^{\prime \prime} \mathrm{N}, 20^{\circ} 19^{\prime} 10.21^{\prime \prime} \mathrm{E}, 246 \mathrm{~m}$ a.s.l.) in 2009-2011. The trial was established on a leached vertisol acidic in reaction $\left(\mathrm{pH}_{\mathrm{H} 2 \mathrm{O}} 4.8\right)$, which contained $3.2 \%$ organic matter. The soil was well supplied with 
286

phosphorus (22.1 mg $\left.100 \mathrm{~g}^{-1}\right)$ and potassium (30.0 mg $100 \mathrm{~g}^{-1}$ soil), had a moderate content of cobalt (27.2 mg $\mathrm{kg}^{-1}$ soil), low levels of calcium $\left(0.01 \% \mathrm{CaCO}_{3}\right)$ and boron $\left(0.06 \mathrm{mg} \mathrm{kg}^{-1}\right.$ soil), and a relatively high concentration of aluminium ions $\left(12.0 \mathrm{mg} \mathrm{kg}^{-1}\right.$ soil). The preceding crop was natural meadow. In autumn, in the year before sowing, $45 \mathrm{~kg} \mathrm{ha}^{-1} \mathrm{~N}, 45 \mathrm{~kg} \mathrm{ha}^{-1} \mathrm{P}_{2} \mathrm{O}_{5}$ and $45 \mathrm{~kg} \mathrm{ha}^{-1} \mathrm{~K}_{2} \mathrm{O}$ (NPK 15:15:15) were incorporated into the soil through primary tillage.

\section{Experimental design}

The experiment, involving treatments as combinations of four red clover cultivars and four foliar fertilisation variants (unfertilised, cobalt, boron and phosphorus-potassium), was laid out in a randomised block design with four replications and with a plot size of $5 \mathrm{~m}^{2}$. Four red clover cultivars, differing in total biomass production and leaf proportion, namely 'K-17', 'K-39' (Institute of Forage Crops, Kruševac, Serbia), 'Una' (Institute of Field and Vegetable Crops, Novi Sad, Serbia) and 'Viola' (a Polish cultivar) were planted in two consecutive years (2009 and 2010, on 28 and 30 March, respectively) at a row spacing of $0.2 \mathrm{~m}$ and a seeding rate of $18 \mathrm{~kg} \mathrm{ha}^{-1}$. Foliar treatments included: unfertilised control; cobalt applied as $\mathrm{Co}\left(\mathrm{NO}_{3}\right)_{2}$ at a concentration of $0.033 \mathrm{~g} \mathrm{~L}^{-1}$ with a water rate of $1000 \mathrm{~L} \mathrm{ha}^{-1}$ in two applications, one at the stage of intensive growth, i.e. stage 34-36 of the BBCH scale (Meier, 2001) during the first cut and two applications during the second cut in the second year of cultivation - the first at $\mathrm{BBCH} 34-36$; active vegetative growth, and the second at BBCH 51-55; just before flowering; boron (Boron-feed, Haifa, Israel) applied at a concentration of $0.1 \%$, with a water rate of $1000 \mathrm{~L} \mathrm{ha}^{-1}$, at the stage of intensive growth during the second cut; and phosphorus combined with potassium $\left(\mathrm{P}_{52} \mathrm{~K}_{34}\right.$, Haifa, Israel), applied at a concentration of $1 \%$ with a water rate of $1000 \mathrm{~L}$ $\mathrm{ha}^{-1}$, at the same growth stage as boron. Boron and phosphorus fertilisers were applied at the manufacturer's recommended concentrations, while the application rate of cobalt was used according to Vranný (1978).

Seeds were collected at full maturity (12\% seed moisture content) in July 2010 and July 2011 in the second year of cultivation. Harvested seeds were cleaned manually, placed into paper bags and stored at room temperature $\left(15-20^{\circ} \mathrm{C}\right.$ during summer, and $5-15^{\circ} \mathrm{C}$ in winter) and at a relative humidity below $50 \%$.

\section{Measurements}

Analyses were performed in three periods i.e. one, eight and twenty months after seed harvest. In Southeast Europe, red clover seed is harvested mostly from the second cut, in late July and early August. In this region, red clover sowing in autumn is performed from the end of August to late September, when the seed is approximately one month old. Sowing in the spring of the following year begins after eight-month storage of seeds from the previous year. Twelve months later (at the time of the following spring sowing), the seed is about twenty months old. In these periods, four replicates of 100 seeds per treatment and field replication were germinated on filter paper, according to the ISTA Rules (ISTA, 2011). Seeds were germinated at $20^{\circ} \mathrm{C}$ in dark germination cabinets. To overcome hardseededness, seeds were subjected to precooling at $3^{\circ} \mathrm{C}$ for 7 days (Uzun and Aydin, 2004). Final germination and hardseededness were determined 10 days later by identifying the number of normally germinated seeds and number of hard seeds, respectively, and expressing them as percentages. Measurement of seedling growth parameters (primary root length, shoot length and fresh seedling biomass, i.e. root and shoot) was done after final germination. Seedling length was measured by a ruler and fresh seedling biomass was determined using an analytical balance (Shimadzu, Japan). At the end, the sum of total root length, total shoot length and total seedling mass per replication were calculated. Considering large differences in germination percentage among seeds after one, eight and twenty months of storage, the values of primary root length, shoot length and fresh seedling biomass for both years and treatments (Table 1) are expressed as mean values per seedling.

\section{Statistical analysis}

The obtained results were subjected to a two-factor analysis of variance (cultivars and foliar fertilisation as fixed effects) using SPSS (SPSS 1995). Given that there were no significant differences between years, as well 
as significant interactions between year and other factors, the analysis of variance was performed using average values. To correct for normality, the statistical analysis was performed on $\sqrt{a r c s i n e}$ transformed values for final germination and on $\sqrt{ } \mathrm{x}+1$ for hard seededness. The significance of differences between storage periods was tested by $\mathrm{t}$-test, and between cultivars and foliar fertilisation treatments by LSD test.

\section{Results}

Averaged across years, cultivars and foliar treatments, significantly higher seed germination, resulting from the significantly lower number of hard seeds, was recorded in seeds after eight and twenty months of storage, compared with seeds after one-month storage (Table 1).

After one month of storage, the proportion of hard seeds was $52.8 \%$ on average for all cultivars, this being the main reason for the very low germination percentage (24.8\%).

After eight months' storage, germination percentage was increased to $89.6 \%$ and the proportion of hard seeds was reduced to $1.6 \%$. After eight months, seedling growth parameters didn't change at seeds that were stored for one month $(\mathrm{P}>0.05)$ (Table 1$)$. At the same time, the proportion of dead seeds and abnormal seedlings was reduced by more than twice. Germination percentage and seedling growth parameters were not significantly affected by the prolongation of the storage period, i.e. there were no differences between eightmonth and twenty-month storage periods. However, the proportion of hard seeds was reduced more than twice, although the difference was not significant.

For each storage period, there were also differences among cultivars in germination percentage (except for one-month storage), root length, stem length (only for one-month storage), seedling mass and the number of hard seeds (Table 2). These differences among cultivars were consistent across foliar fertilisation treatments (the absence of the cultivar/fertilisation interaction) in all storage periods.

Foliar fertilisation with cobalt in this experiment had no effect on germination percentage (Table 2), regardless of storage period. Seeds from foliar cobalt treatment had a significantly greater seedling root length compared to the unfertilised crop after one-month storage; eight-month-old seeds had significantly lower values, whereas no significant differences were observed in seeds after twenty months of storage.

Foliar-applied boron did not affect germination percentage, regardless of the length of the storage period (Table 2). Germination percentage was significantly higher after boron treatment than after cobalt treatment in eight-month-old seeds and phosphorus-potassium treatment in seeds after twenty-month storage. Seedling root length was significantly greater after foliar boron application than in the unfertilised control only after one month of storage. Significantly greater seedling mass was observed following boron treatment compared to cobalt treatment and the unfertilised control after eight months of storage and compared to phosphoruspotassium treatment after twenty months of storage.

Foliar fertilisation with phosphorus-potassium had no significant effect on germination percentage and seedling growth parameters in any storage period (Table 2).

Positive correlations were observed among germination percentage, stem length, root length and seedling mass, while, expectedly, the proportion of hard seeds was negatively correlated with all other characteristics (Table 3).

Table 1. Mean values of germination percentage, stem length, fresh seedling mass and dormant seed of red clover depending on storage period (average for years, cultivars and foliar treatments)

\begin{tabular}{|c|c|c|c|c|c|c|}
\hline $\begin{array}{c}\text { Storage } \\
\text { period }\end{array}$ & $\begin{array}{c}\text { Germination } \\
(\%)\end{array}$ & $\begin{array}{c}\text { Stem length } \\
(\mathrm{mm})\end{array}$ & $\begin{array}{c}\text { Root length } \\
(\mathrm{mm})\end{array}$ & $\begin{array}{c}\text { Seedling mass } \\
(\mathrm{mg})\end{array}$ & $\begin{array}{c}\text { Hard seed } \\
(\%)\end{array}$ & $\begin{array}{c}\text { Dead } \\
\text { seed/abnormal } \\
\text { seedling }(\%)\end{array}$ \\
\hline 1 month & $24.8 \pm 1.45 \mathrm{~b}$ & $36.3 \pm 2.67 \mathrm{a}$ & $37.2 \pm 2.76 \mathrm{a}$ & $27.7 \pm 2.47 \mathrm{a}$ & $52.8 \pm 1.86 \mathrm{a}$ & $22.4 \pm 1.26 \mathrm{a}$ \\
\hline 8 months & $89.6 \pm 0.85 \mathrm{a}$ & $35.3 \pm 0.72 \mathrm{a}$ & $35.2 \pm 1.05 \mathrm{a}$ & $25.6 \pm 0.67 \mathrm{a}$ & $1.58 \pm 0.33 \mathrm{~b}$ & $8.8 \pm 0.53 \mathrm{~b}$ \\
\hline
\end{tabular}


Tomic D et al. (2020). Not Bot Horti Agrobo 48(1):284-293

288

\begin{tabular}{|c|c|c|c|c|c|c|}
\hline 20 months & $88.4 \pm 0.96 \mathrm{a}$ & $38.7 \pm 1.27 \mathrm{a}$ & $35.7 \pm 1.29 \mathrm{a}$ & $25.9 \pm 0.45 \mathrm{a}$ & $0.67 \pm 0.18 \mathrm{~b}$ & $10.9 \pm 0.57 \mathrm{~b}$ \\
\hline
\end{tabular}
Data represent mean \pm s.d. Mean values in each storage period followed by the same letter are not significantly different
$(P>0.05)$.

Table 2. Mean values of seed quality traits of red clover cultivars ('K-39', 'K-17', 'Una', 'Viola') depending on foliar fertilisation (unfertilised, cobalt - Co, boron - B, phosphorus-potassium - PK) in different storage periods $(\mathrm{n}=48)$

\begin{tabular}{|c|c|c|c|c|c|c|}
\hline $\begin{array}{l}\text { Storage } \\
\text { period }\end{array}$ & $\begin{array}{c}\text { Cultivar/ } \\
\text { Foliar } \\
\text { fertilisation }\end{array}$ & $\begin{array}{l}\text { Germination } \\
(\%)\end{array}$ & $\begin{array}{l}\text { Stem length } \\
(\mathrm{cm})\end{array}$ & $\begin{array}{l}\text { Root length } \\
(\mathrm{cm})\end{array}$ & $\begin{array}{l}\text { Seedling mass } \\
\text { (g) }\end{array}$ & $\begin{array}{l}\text { Hard seed } \\
\qquad \%)\end{array}$ \\
\hline \multirow{10}{*}{$\begin{array}{l}\text { One } \\
\text { month }\end{array}$} & 'K-39' & $28.8 \pm 3.66$ & $58.5 \pm 8.63 \mathrm{a}$ & $53.8 \pm 10.16 \mathrm{a}$ & $0.441 \pm 0.06 \mathrm{a}$ & $49.2 \pm 5.08 \mathrm{~b}$ \\
\hline & ‘K-17’ & $22.8 \pm 2.57$ & $39.3 \pm 5.15 \mathrm{~b}$ & $46.1 \pm 6.15 \mathrm{ab}$ & $0.321 \pm 0.04 \mathrm{~b}$ & $52.5 \pm 3.88 \mathrm{ab}$ \\
\hline & 'Una' & $23.0 \pm 2.28$ & $38.8 \pm 6.05 \mathrm{~b}$ & $49.1 \pm 5.37 \mathrm{ab}$ & $0.314 \pm 0.03 \mathrm{~b}$ & $57.2 \pm 2.01 \mathrm{a}$ \\
\hline & 'Viola' & $24.5 \pm 2.91$ & $44.1 \pm 5.30 \mathrm{ab}$ & $36.5 \pm 4.22 \mathrm{~b}$ & $0.298 \pm 0.04 \mathrm{~b}$ & $52.3 \pm 3.33 \mathrm{ab}$ \\
\hline & $\mathrm{P}^{1}$ & $\mathrm{~ns}$ & $*$ & $*$ & $* *$ & * \\
\hline & Unfertilised & $23.2 \pm 2.61$ & $45.6 \pm 8.63$ & $34.2 \pm 2.28 \mathrm{~b}$ & $0.326 \pm 0.04$ & $54.3 \pm 3.72 \mathrm{ab}$ \\
\hline & $\mathrm{Co}$ & $27.0 \pm 2.54$ & $49.9 \pm 5.70$ & $54.5 \pm 6.35 \mathrm{a}$ & $0.362 \pm 0.04$ & $51.5 \pm 3.19 \mathrm{ab}$ \\
\hline & $\mathrm{B}$ & $27.0 \pm 3.78$ & $45.5 \pm 7.28$ & $59.2 \pm 9.86 \mathrm{a}$ & $0.389 \pm 0.06$ & $47.0 \pm 3.66 \mathrm{~b}$ \\
\hline & PK & $22.0 \pm 2.52$ & $39.5 \pm 4.87$ & $37.7 \pm 4.26 \mathrm{~b}$ & $0.299 \pm 0.03$ & $58.3 \pm 3.91 \mathrm{a}$ \\
\hline & $\mathrm{P}$ & $\mathrm{ns}$ & $\mathrm{ns}$ & $* * *$ & $\mathrm{~ns}$ & * \\
\hline \multirow{10}{*}{$\begin{array}{l}\text { Eight } \\
\text { months }\end{array}$} & 'K-39' & $92.83 \pm 1.64 \mathrm{a}$ & $157.4 \pm 5.51$ & $173.4 \pm 7.71 \mathrm{a}$ & $1.258 \pm 0.05 \mathrm{a}$ & $1.33 \pm 0.62 \mathrm{ab}$ \\
\hline & ‘K-17’ & $88.17 \pm 1.88 \mathrm{~b}$ & $161.5 \pm 3.87$ & $146.0 \pm 7.25 \mathrm{~b}$ & $1.157 \pm 0.08 \mathrm{a}$ & $0.33 \pm 0.22 \mathrm{~b}$ \\
\hline & 'Una' & $90.17 \pm 1.78 \mathrm{ab}$ & $164.7 \pm 9.87$ & $170.1 \pm 9.33 \mathrm{a}$ & $0.989 \pm 0.04 \mathrm{~b}$ & $2.00 \pm 0.69 \mathrm{a}$ \\
\hline & 'Viola' & $87.17 \pm 1.14 \mathrm{~b}$ & $149.7 \pm 4.61$ & $142.1 \pm 10.60 \mathrm{~b}$ & $1.184 \pm 0.06 \mathrm{a}$ & $2.67 \pm 0.79 \mathrm{a}$ \\
\hline & $\mathrm{P}$ & $*$ & $\mathrm{~ns}$ & ** & ** & * \\
\hline & Unfertilised & $89.67 \pm 1.67 \mathrm{ab}$ & $150.4 \pm 5.50$ & $166.0 \pm 9.15 \mathrm{a}$ & $1.082 \pm 0.06 \mathrm{bc}$ & $1.17 \pm 0.57$ \\
\hline & $\mathrm{Co}$ & $86.01 \pm 1.83 \mathrm{~b}$ & $159.2 \pm 4.91$ & $142.3 \pm 9.48 \mathrm{~b}$ & $1.019 \pm 0.03 \mathrm{c}$ & $2.50 \pm 0.89$ \\
\hline & $\mathrm{B}$ & $92.52 \pm 1.56 \mathrm{a}$ & $159.0 \pm 3.41$ & $158.4 \pm 9.39 \mathrm{ab}$ & $1.285 \pm 0.08 \mathrm{a}$ & $1.00 \pm 0.46$ \\
\hline & PK & $90.17 \pm 1.38 \mathrm{ab}$ & $164.8 \pm 10.0$ & $164.8 \pm 9.39 \mathrm{ab}$ & $1.202 \pm 0.06 \mathrm{ab}$ & $1.67 \pm 0.59$ \\
\hline & $\mathrm{P}$ & * & $\mathrm{ns}$ & $*$ & ** & $\mathrm{ns}$ \\
\hline \multirow{10}{*}{$\begin{array}{l}\text { Twenty } \\
\text { months }\end{array}$} & 'K-39' & $91.5 \pm 1.44 \mathrm{a}$ & $164.8 \pm 12.8$ & $173.4 \pm 7.71 \mathrm{a}$ & $1.086 \pm 0.03 \mathrm{c}$ & $0.5 \pm 0.26 \mathrm{ab}$ \\
\hline & 'K-17' & $91.17 \pm 2.17 \mathrm{a}$ & $175.6 \pm 14.7$ & $144.2 \pm 7.21 \mathrm{ab}$ & $1.191 \pm 0.04 \mathrm{~b}$ & $0.17 \pm 0.17 \mathrm{~b}$ \\
\hline & 'Una' & $87.83 \pm 1.45 \mathrm{ab}$ & $173.6 \pm 9.48$ & $157.3 \pm 15.8 \mathrm{ab}$ & $1.284 \pm 0.05 \mathrm{a}$ & $0.67 \pm 0.28 \mathrm{ab}$ \\
\hline & 'Viola' & $83.17 \pm 1.69 \mathrm{~b}$ & $180.6 \pm 8.42$ & $142.1 \pm 10.6 \mathrm{~b}$ & $1.021 \pm 0.04 \mathrm{c}$ & $1.33 \pm 0.57 \mathrm{a}$ \\
\hline & $\mathrm{P}$ & ** & $\mathrm{ns}$ & * & $* * *$ & * \\
\hline & Unfertilised & $88.17 \pm 2.33 \mathrm{ab}$ & $163.5 \pm 9.16$ & $151.6 \pm 15.45$ & $1.12 \pm 0.03 \mathrm{ab}$ & $1.17 \pm 0.57$ \\
\hline & $\mathrm{Co}$ & $89.83 \pm 1.66 \mathrm{a}$ & $189.3 \pm 13.9$ & $142.4 \pm 9.48$ & $1.174 \pm 0.04 \mathrm{ab}$ & $0.67 \pm 0.28$ \\
\hline & $\mathrm{B}$ & $91.0 \pm 1.77 \mathrm{a}$ & $166.9 \pm 12.4$ & $158.4 \pm 9.39$ & $1.185 \pm 0.07 \mathrm{a}$ & $0.17 \pm 0.17$ \\
\hline & PK & $84.67 \pm 1.56 \mathrm{~b}$ & $174.9 \pm 9.22$ & $164.8 \pm 9.39$ & $1.103 \pm 0.04 \mathrm{~b}$ & $0.67 \pm 0.28$ \\
\hline & $\mathrm{P}$ & * & $\mathrm{ns}$ & $\mathrm{ns}$ & $*$ & $\mathrm{~ns}$ \\
\hline
\end{tabular}

Data represent mean \pm s.d. Mean values in each storage period for cultivars and foliar fertilisation treatments followed by the same letter are not significantly different $(P>0.05) .{ }^{1} P$ indicates the significance of the cultivar and foliar fertilisation effects in the analysis of variance. $\mathrm{ns}$ - non-significant, ${ }^{*}-\mathrm{P}<0.05,{ }^{* *}-\mathrm{P}<0.01,{ }^{* * *}-\mathrm{P}<0.001$

Table 3. Coefficients of correlation among germination rate, stem length, root length and seedling mass $(\mathrm{n}=144)$

\begin{tabular}{|c|c|c|c|c|}
\hline Traits & $\begin{array}{c}\text { Stem length } \\
(\mathrm{cm})\end{array}$ & $\begin{array}{c}\text { Root length } \\
(\mathrm{cm})\end{array}$ & $\begin{array}{c}\text { Seedlings mass } \\
(\mathrm{g})\end{array}$ & $\begin{array}{c}\text { Hard seed } \\
(\%)\end{array}$ \\
\hline Germination $(\%)$ & $0.90^{*}$ & $0.87^{*}$ & $0.94^{*}$ & $-0.96^{*}$ \\
\hline Stem length $(\mathrm{cm})$ & & $0.76^{*}$ & $0.85^{*}$ & $-0.88^{*}$ \\
\hline Root length $(\mathrm{cm})$ & & & $0.80^{*}$ & $-0.84^{*}$ \\
\hline
\end{tabular}


Seedling mass $(\mathrm{g})$

* Significant at $\mathrm{P}<0.05$

$-0.90^{*}$

\section{Discussion}

Hard seededness is a common trait in species of the genera Medicago and Trifolium. Some ecotypes of species belonging to these genera, immediately after harvest, may have hard seededness at a rate of up to $100 \%$ (James et al., 1970; Crawford et al., 1989; Aydin and Uzun, 2001; Can et al., 2009). Colgecen et al. (2008) found the germination percentage of $13.5 \%$ immediately after harvest in red clover seeds from natural populations. The higher germination percentage in this research may be due to the agro-environmental conditions of the experimental location, cultivar or, possibly, seed chilling before the germination test was performed.

Smýkal et al. (2014) observed that, under natural conditions, in temperate-zone species, there are two steps in breaking dormancy by low winter temperatures. During the first step, low winter temperatures make seeds sensitive to alternating temperatures, and during the second step, these alternating regimes occurring in early spring cause the sensitive seeds to become water-permeable. Seeds can only respond to alternating spring temperatures if they become sensitive during the winter (Baskin and Baskin, 2014). Accordingly, the authors pointed out that several artificial techniques are used to break physical dormancy in seeds, such as dry storage i.e. low temperatures.

In the present experiment, during the winter, seeds were kept at low temperatures (from +5 to $+15^{\circ} \mathrm{C}$ ); along with ageing, this chilling treatment reduced hard seededness. Consequently, in eight-and twenty-monthold seeds, there was an increase in germination percentage and seedling growth parameters, as well as a significant reduction in the proportion of hard seeds, especially in twenty-month-old seeds. Balouch and Modarres (2006) reported that the proportion of hard seeds in red clover decreased and, consequently, germination percentage increased with ageing and also after chilling treatment.

Differences among cultivars in germination percentage, root length, seedling mass and the number of hard seeds in any storage period can be attributed to the high genetic variability of red clover as a species (Steiner et al., 1995; Helgadottir, 1996; Zielinska et al., 2012). Acharya et al. (1999) reported that the percentage of hard seededness in alfalfa largely depends on cultivar. Also, when studying the influence of different pre-sowing treatments on dormancy breakdown, germination and vigour of red clover seeds, Simić et al. (2018) observed significant differences in the proportion of hard seeds among red clover cultivars.

In the future, as more emphasis is placed on seed quality, the need for the classification of cultivars based on seed quality traits will increase (Zielinska et al., 2012).

As determined by Zeid (2001) and Jayakumar et al. (2007), cobalt content in soil up to $50 \mathrm{mg} \mathrm{kg}^{-1}$ was progressively increased germination percentage, while higher concentrations negatively affected this trait. The foliar application of cobalt in this experiment had different effects on seedling root length in seeds after different periods of storage.

Germination percentage in all foliar fertilisation treatments did not significantly differ from the unfertilised control. This result is in agreement with the findings of Stoltz and Wallenhammar (2013), who, on a soil with a very low content of boron $\left(<1 \mathrm{mg} \mathrm{kg}^{-1}\right)$, found a smaller (although non-significant) proportion of ungerminated red clover seeds under soil/foliar boron treatment compared to the control. The authors also emphasised that higher boron concentrations in seeds increased the percentage of normal seedlings and reduced the proportion of hard seeds. On the contrary, Ćwintal et al. (2010) on a soil with a very low content of boron $\left(1.1 \mathrm{mg} \mathrm{kg}^{-1}\right)$ reported a positive effect of foliar boron fertilisation on the germination percentage and germination energy of red clover seeds. Also, foliar boron application favoured the seed germination and viability of alfalfa (Medicago sativa L.) seeds on the calcareous loam soil (Dordas, 2006). As indicated by Dos 
290

Santos et al. (2004), boron deficiency leads to necrosis of the meristematic tissue and reduces root system growth in alfalfa. Numerous studies have confirmed the positive effect of boron, applied as a solution for seed treatment, on the proportion of hard seeds, germination percentage and seedling growth parameters in many plants (Rerkasem et al., 1997; Farooq et al., 2011; Mirshekari, 2012; Rehman et al., 2012). However, the use of boron at high concentrations may exhibit a toxic effect (Bonilla et al., 2004; Farooq et al., 2011). In the present research (except the second cobalt treatment), foliar treatments were applied at $\mathrm{BBCH} 34-36$. The period from this stage to the beginning of flowering (at $\mathrm{BBCH}$ 60-62) under given agro-environmental conditions, depending on the sum of active temperatures, is 14-25 days. Overall, the positive effect of foliar-applied mineral nutrients is time-limited, lasting generally up to 15 days (Brown and Shelp, 1997). The period from fertilisation to physiological maturity (at $\mathrm{BBCH} 85$ ) in red clover is 25 days on average (Angsumalee et al., 2016). This may explain the absence of significant effect of foliar boron fertilisation on seed quality traits.

The positive effect of phosphorus and potassium, applied as a solution for seed treatment before germination, on germination percentage and subsequent stages of plant development, as well as on total yield in many plant species, has been shown in numerous reports (Kalita et al., 2002; Yang et al., 2004; Zel,onka et al., 2005; Ali et al., 2008). In this study, foliar fertilisation with phosphorus-potassium could not have a significant effect on germination percentage and seedling growth parameters in any storage period. As with boron, the absence of the positive effect of these nutrients on seed quality can be associated with their earlier application. The positive effect of foliar-applied cobalt, which was also supplied immediately before flowering, on red clover seed yield has been reported by Tomić et al. (2014). However, the available literature provides no data on the effect of cobalt on seed quality traits after its foliar application.

\section{Conclusions}

Seeds of all cultivars had low germination percentages after one month of storage, due to the high proportion of hard seeds. In all foliar fertilisation treatments, red clover cultivars differed in hard seededness, root length and seedling mass at all storage periods, but their differences were inconsistent. In any storage period, foliar treatments did not affect germination, stem length, seedling mass and percentage of hard seed in any cultivar (no significant cultivar/foliar treatment interaction). At 20 months of storage, there were no significant differences between foliar treatments and the unfertilised control in any of the studied traits. Foliar nutrients were applied prior to the emergence of generative organs; therefore, the absence of their positive effect on seed development can be associated with their overall short-term effect. Further research should focus on the relationship between seed quality and the content of macro- and micronutrients in the seed under different crop nutrient management practices, especially their foliar application at different stages of plant growth.

\section{Acknowledgements}

This work is part of the research project Ref. No. TR-31016 funded by the Ministry of Education, Science and Technological Development, Republic of Serbia.

\section{Conflict of Interests}

The authors declare that there are no conflicts of interest related to this article. 


\section{References}

Abbasi H, Jamil M, Haq A, Ali S, Ahmad R, Malik Z, Parveen Z (2016). Salt stress manifestation on plants, mechanism of salt tolerance and potassium role in alleviating it: a review. Zemdirbyste-Agriculture 103:229-238.

Acharya SN, Stout DG, Brooke B, Thompson D (1999). Cultivar and storage effect on germination and hard seed content of alfalfa. Canadian Journal of Plant Science 79:201-208.

Ali S, Khan RA, Mairaj G, Arif M, Fida M, Bibi S (2008). Assessment of different crop nutrient management practices for yield improvement. Australian Journal of Crop Science 2:150-157.

Asci OO, Acar Z, Ayan I, Basaran U, Mut H (2011). Effect of pre-treatments on seed germination rate of red clover (Trifolium pratense L.) populations. African Journal of Agricultural Research 613:3055-3070.

Angsumalee D (2016). Effect of plant growth regulator and irrigation on physiological and harvest maturity of red clover in relation to seed quality. PhD Thesis in Crop Science presented, Oregon State University.

Ates E (2011). Influence of some hardseededness-breaking treatments on germination in Persian clover (Trifolium resupinatum ssp. typicum flori Paol.) seeds. Romanian Agricultural Research 28:229-236.

Austenfeld FA (1979). Effects of nickel, cobalt and chromium on net photosynthesis of primary and secondary leaves of Phaseolus vulgaris cultivar saxa. Photosynthetica 13:434-438.

Aydin I, Uzun F (2001). The effects of some applications on germination rate of gentlemen clover seeds gathered from natural vegetation in Samsun. Pakistan Journal of Biological Science 4:181-183.

Balouchi HR, Modarres SSYM (2006). Effect of gibberellic acid, prechilling, sulfuric acid and potassium nitrate on seed germination and dormancy of annual Medics. Pakistan Journal of Biological Science 9:2875-2880.

Baskin CC, Baskin JM (2014). Germination ecology of seeds with physical dormancy. In: Seeds: ecology, biogeography and evolution of dormancy and germination. 2nd Edition, Academic/Elsevier, San Diego, USA, pp 101-132.

Baskin JM, Baskin CC (2004). A classification system for seed dormancy. Seed Science Research 14:1-16.

Bonilla I, El-Hamdaoui A, Bolanos L (2004). Boron and calcium increase Pisum sativum seed germination and seedling development under salt stress. Plant and Soil 267:97-107.

Brown HP, Shelp JB (1997). Boron mobility in plants. Plant and Soil 193:85-101.

Can E, Celiktas N, Hatipoglu R, Avci S (2009). Breaking seed dormancy of some annual Medicago and Trifolium species by different treatments. Turkish Journal of Field Crops 14:72-78.

Colgecen H, Buyukkartal HN, Toker MC (2008). In vitro germination and structure of hard seed testa of natural tetraploid Trifolium pratense L. African Journal of Biotechnology 7:1473-1478.

Collins NR, Kinsela SA (2011). Pedogenic factors and measurements of the plant uptake of cobalt. Plant and Soil 339:499-512.

Copeland LO, McDonald MB (1995). Principles of seed science and technology. Kluwer Academic Publisher, Springer US, USA, pp 435.

Crawford EJ, Lake AVH, Boyce KG (1989). Breeding annual Medicago species for semiarid conditions in southern Australia. Advances in Agronomy 42:399-437.

Ćwintal M, Sowa P, Goliasz S (2010). Influence of microelements (B, Mo) and laser stimulation on sowing value of red clover seeds. Acta Agrophysica 15:65-76.

Danilova TA, Tischenko IV, Demkina EN (1970). Distribution and movement of cobalt in leguminous plants. Agrokhimiya 2:100.

Desai BB, Kotecha PM, Salunkhe DK (1997). Seeds handbook biology, production, processing, and storage. Marcel Dekker Inc., New York, USA, pp 627.

Dordas C (2006). Foliar boron application improves seed set, seed yield, and seed quality of alfalfa. Agronomy Journal 98:907913.

Dos Santos RA, De Mattos T, Da Silva Almeida A, Monteiro AF, Correa DB, Gupta CU (2004). Boron nutrition and yield of alfalfa cultivar 'Crioula' in relation to boron supply. Scientia Agricola 61:496-500.

Farooq M, Rehman A, Aziz T, Habib M (2011). Boron nutri-priming improves the germination and early seedling growth of rice (Oryza sativa L.). Journal of Plant Nutrition 34:1507-1515.

Goldbach HE, Yu Q, Wingender R, Schulz M, Wimmer M, Findeklee P, Baluka F (2001). Rapid response reactions of roots to boron deprivation. Journal of Plant Nutrition and Soil Science 164:173-181. 
Hégh-Jensen H, Fabricius V, Schjoerring KJ (2001). Regrowth and nutrient composition of different plant organs in grass-clover canopies as affected by phosphorus and potassium availability. Annals of Botany 88:153-162.

Helgadottir A (1996). Legumes in Icelandic agriculture. Grassland and land use systems. Grassland Science in Europe 1:741-745. ISTA (2011). International rules for seed testing. International Seed Testing Association. Zurich, Austria, pp 1-45.

James AY, Raymond AE, Burgess LK (1970). Germination characteristic of range legumes. Journal of Range Management 23:98-103.

Jayakumar K, Jallel AC (2009). Uptake and accumulation of cobalt in plants: a study based on exogenous cobalt in soybean. Botany Research International 2:310-314.

Jayakumar K, Jallel AC, Vijayarengan P (2007). Changes in growth, biochemical constituents and antioxidant potentials in radish (Raphanus sativus L.) under cobalt stress. Turkish Journal of Botany 31:127-136.

Kalita U, Suhrawardy J, Das RJ (2002). Effect of seed priming with potassium salt and potassium levels on growth and yield of direct seeded summer rice (Oryza sativa L.) under rainfed upland condition. Indian Journal of Hill Farming 15:50-53.

Mathur N, Singh J, Bohra S, Bohra A, Vyas A (2006). Effect of soil compaction potassium and cobalt on growth and yield of moth bean. International Journal of Soil Science 1:269-271.

Matsumoto H (2000). Cell biology of aluminum toxicity and tolerance in higher plants. International Review of Cytology 200:146.

Meier U (2001). Growth stages of mono-and dicotyledonous plants. BBCH Monographs, 2nd Edition, Volume 1 (ed. Uwe Meier), Federal Biological Research Centre for Agriculture and Forestry, BBCH Publ, Germany, pp 6-13.

Mirshekari B (2012). Seed priming with iron and boron enhances germination and yield of dill (Anethum graveolens). Turkish Journal of Agriculture and Forestry 36:27-33.

Palit S, Sharma A, Talukder G (1994). Effects of cobalt on plants. The Botanical Review 60:149-173.

Rehman UA, Farooq M, Nawaz A, Iqbal S, Rehman A (2012). Optimizing the boron seed coating treatments for improving the germination and early seedling growth of fine grain rice. International Journal of Agriculture and Biology 14:453-456.

Rerkasem B, Bell WR, Lordkaew S, Loneragan FJ (1997). Relationship of seed boron concentration to germination and growth of soybean (Glycine max L. Merr.). Nutrient Cycling in Agroecosystems 48:217-223.

Sawan MZ, Fahmy HA, Yousef ES (2009). Direct and residual effects of nitrogen fertilization, foliar application of potassium and plant growth retardant on Egyptian cotton growth, seed yield, seed viability and seedling vigour. Acta Ecologica Sinica 29:116-123.

Simić A, Štrbanović R, Poštić D (2018). Influence of different pre-sowing treatments on seed dormancy breakdown, germination and vigour of red clover and Italian ryegrass. International Journal of Agriculture and Biology 20:1548-1554.

Smýkal P, Vernoud V, Blair WM, Soukup A, Thompson DR (2014). The role of the testing during development and in establishment of dormancy of the legume seed. Frontiers in Plant Science 5:1-19.

SPSS. Inc. (1995). STATISTICA for Windows (Computer Program Manual), Tulsa, OK, USA.

Steiner JJ, Leffel JA, Gingrich G, Aldrich-Markham S (1995). Red clover seed production: III Effect of herbage removal time under varied environments. Crop Science 35:1667-1675.

Stoltz E, Wallenhammar AC (2013). Influence of boron in organic red clover (Trifolium pratense L.) seed production. Grass and Forage Science 69:285-293.

Tomić D, Stevović V, Đurović D (2011). The influence of foliar application of phosphorous and potassium on seed yield and yield components of red clover genotypes (Trifolium pratense L.). Proceedings of the 16th Conferences of Biotechnology, Faculty of Agronomy in Agronomy, Čačak, Serbia, pp 65-71.

Tomić D, Stevović V, Đurović D, Stanisavljević R (2014). Effect of cobalt application on seed production in red clover (Trifolium pratense L.). Journal of Agricultural and Science Technology 16:517-526.

Tomić D, Stevović V, Đurović D, Madić M, Bokan N, Stanisavljević R (2015). Boron application in red clover (Trifolium pratense L.) seed production. Irish Journal of Agricultural and Food Research 54:59-63.

Uzun F, Aydin I (2004). Improving germination rate of Medicago and Trifolium species. Asian Journal of Plant Sciences 3:714717.

Vranný J (1978). Microbial changes in clover rhizosphere after foliar and soil application of cobalt. Folia Microbiologica 23:236242. 
Waqar A, Munir HZ, Sukhdev SM, Abid N, Saifullah N (2012). Crop plant. In: Goyal A (Ed). Boron deficiency in soils and crops: a review. Publisher InTech, pp 77-114. Retrieved 20 August 2018 from https://www.intechopen.com/books/cropplant/boron-deficiency-in-soils-and-crops-a-review

Yang EX, Liu XJ, Wang MW, Ye QZ, Luo CA (2004). Potassium internal use efficiency relative to growth vigour, potassium distribution, and carbohydrate allocation in rice genotypes. Journal of Plant Nutrition 27:837-852.

Yau SK (2000). Soil-boron affects straw quality and other agronomic traits in two cultivars of barley. Communications in Soil Science and Plant Analysis 31:591-604.

Zeid MI (2001). Responses of Phaseolus vulgaris to chromium and cobalt treatments. Biologia Plantarum 44:111-115.

Zel̦onka L, Stramkale V, Vikmane M (2005). Effect and after effect of barley seed coating with phosphorus on germination, photosynthetic pigments and grain yield. Acta Universitatis Latviensis Biology 691:111-119.

Zheng JS (2010). Crop production on acidic soils: overcoming aluminium toxicity and phosphorus deficiency. Annals of Botany 106:183-184.

Zielinska M, Zapotoczny P, Białobrzewski I, Zuk-Golaszewska K, Markowski M (2012). Engineering properties of red clover (Trifolium pratense L.) seeds. Industrial Crops and Products 37:69-75.

OPEN ACCESS

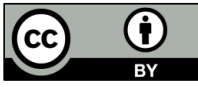

The journal offers free, immediate, and unrestricted access to peer-reviewed research and scholarly work. Users are allowed to read, download, copy, distribute, print, search, or link to the full texts of the articles, or use them for any other lawful purpose, without asking prior permission from the publisher or the author.

License - Articles published in Notulae Botanicae Horti Agrobotanici Cluj-Napoca are Open-Access, distributed under the terms and conditions of the Creative Commons Attribution (CC BY 4.0) License. (c) Articles by the authors; UASVM, Cluj-Napoca, Romania. The journal allows the author(s) to hold the copyright/to retain publishing rights without restriction. 